Final article:

Janssen, C., Vanhamme, J., Lindgreen, A., and Lefebvre, C. (2013), "The catch-22 of responsible luxury: effects of luxury product characteristics on consumers' perceptions of fit with corporate social responsibility", Journal of Business Ethics, Vol. 119, No. 1, pp. 45-57. (ISSN 0167-4544)

For full article, please contact LindgreenA@cardiff.ac.uk

Running head: Responsible Luxury

\title{
The Catch-22 of Responsible Luxury: Effects of Luxury Product Characteristics on Consumers' Perception of Fit with Corporate Social Responsibility
}

\author{
Catherine Janssen, Université catholique de Louvain ${ }^{1}$ \\ Joëlle Vanhamme, EDHEC Business School ${ }^{2}$ \\ Adam Lindgreen, University of Cardiff ${ }^{3}$ \\ Cécile Lefebvre, IESEG School of Management ${ }^{4}$
}

\footnotetext{
${ }^{1}$ Catherine Janssen, Ph.D. Candidate \& ICM Fellow, Louvain School of Management, Université catholique de Louvain, 1 Place des Doyens, 1348 Louvain-la-Neuve, Belgium. E-mail: catherine.janssen@uclouvain.be.

${ }^{2}$ Joëlle Vanhamme, Professor in Marketing, EDHEC Business School, 24 avenue Gustave Delory, CS 50411 59057 Roubaix Cedex, France. E-mail: joelle.vanhamme@edhec.edu.

3 Adam Lindgreen, Professor in Marketing, Cardiff Business School, University of Cardiff, Aberconway Building, Colum Drive, Cardiff CF10 3EU, the U.K. E-mail: LindgreenA@cardiff.ac.uk.

${ }^{4}$ Cécile Lefebvre, IESEG School of Management, France; c/o Joëlle Vanhamme.
} 


\title{
The Catch-22 of Responsible Luxury: Effects of Luxury Product Characteristics on Consumers' Perception of Fit with Corporate Social Responsibility
}

\begin{abstract}
The notion of "responsible luxury" may appear as a contradiction in terms. This article investigates the influence of two defining characteristics of luxury products-scarcity and ephemerality—on consumers' perception of the fit between luxury and corporate social responsibility (CSR), as well as how this perceived fit affects consumers' attitudes toward luxury products. A field experiment reveals that ephemerality moderates the positive impact of scarcity on consumers' perception of fit between luxury and CSR. When luxury products are enduring (e.g., jewelry), a scarce product is perceived as more socially responsible than a more widely available one and provokes positive attitudes. However, this effect does not appear for ephemeral luxury products (e.g., clothing). The perceived fit between luxury and CSR mediates the combined effects of scarcity and ephemerality on consumers' attitudes toward luxury products. This study provides valuable insights that luxury brand managers can use to design their CSR and marketing strategies.
\end{abstract}

Key Words: consumers, corporate social responsibility, ephemerality, luxury products, scarcity. 
The notion of "responsible luxury" has received considerable attention in recent years. Growing concerns center particularly on the ethics of actors in the luxury goods sector, as for example when the World Wide Fund for Nature conducted an analysis of the environmental and social performance of the owners of various luxury brands (Bendell and Kleanthous, 2007). An "Uplifting the Earth" report focuses specifically on the ethical performance of luxury jewelry brands (Doyle and Bendell, 2011). Stories in the international press highlight various ethical problems; Gucci was accused of maltreating its employees in its Shenzhen stores (Caixiong, 2011), and fashion houses such as Prada and Dolce \& Gabbana allegedly exploit illegal Chinese immigrants in Tuscan factories (Wilkinson, 2008). The problem of "blood diamonds," mined and sold to fund armed conflicts, also remains a major concern (Perry, 2011). Business ethics thus offers a significant challenge for the luxury goods sector.

In response, luxury brands including Armani, Cartier, and Chanel have initiated corporate social responsibility (CSR) initiatives, designed to minimize or eliminate any negative impacts of their operations on stakeholders, as well as maximize beneficial impacts on society at large (Commission of the European Communities, 2011; Mohr et al., 2001; van Marrewijk, 2003). Other actors in the luxury goods sector also are striving to ensure that their business practices become more socially responsible (Kendal, 2010). According to François-Henri Pinault, Chair and CEO of the Pinault-Printemps-la Redoute group, "the luxury business does not escape the logic that human beings and the planet should be protected together. On the contrary, it should play an important part in achieving that goal, as a model and leader" (Castro, 2009).

Despite these efforts, exploratory findings suggest that consumers may not be responsive to luxury brands' CSR, because ethical considerations carry little weight in their luxury product purchase decisions (Davies et al., 2012). Lack of information might explain this tendency; previous findings concur that consumers generally exhibit low awareness of 
companies' CSR activities (e.g., Pomering and Dolnicar, 2009) and are unlikely to consider CSR as a purchase criterion without enough relevant information (Bray et al., 2011; Öberseder et al., 2011). Perhaps more communication about luxury brands' CSR efforts would increase consumers' awareness of the social and environmental impact of the luxury products they buy.

Yet luxury brands may take a risk with their CSR disclosures, in that recent research suggests consumers do not regard luxury and CSR as compatible. Torelli et al. (2012) find that when a luxury brand communicates about its CSR activities, consumers may perceive that something is "not right" and respond with lower brand evaluations than when the brand provides no such information. Torelli et al. (2012) explain these findings through abstract brand-associated meanings (Park et al., 1991), which affect brand evaluations through the motivations that they activate automatically (Chartrand et al., 2008). According to Schwartz's (1992) circular theory of human values, 10 motivationally distinct values can be categorized into four broad types:

1. Self-enhancement (power, achievement, hedonism; note: hedonism shares elements of both self-enhancement and openness [Schwartz, 1992]), promoting the pursuit of one's own interests;

2. Self-transcendence (universalism, benevolence), which emphasizes concern for the welfare of others;

3. Conservation (security, tradition, conformity) that emphasizes the protection of the status quo; and

4. Openness (self-direction, stimulation, hedonism), or encouraging the pursuit of new ideas and experiences.

Some motivational values conflict (e.g., self-enhancement versus self-transcendence; conservation versus openness), but others are congruent (e.g., self-transcendence and 
conservation; self-transcendence and openness) (Maio et al., 2009; Schwartz, 1992; Schwartz and Rubel, 2005). Whereas CSR emphasizes the welfare of others and concern for the environment, and thus reflects self-transcendence values, luxury tends to be associated primarily with conspicuousness (Han et al., 2010), hedonism (Hagtvedt and Patrick, 2009), and success (Mandel et al., 2006) — concepts that emphasize the consumer's own interests and well-being, or self-enhancement values. Because CSR-associated self-transcendence values appear to conflict with luxury-associated self-enhancement values (Schwartz, 1992; Torelli et al., 2012), the notion of "responsible luxury" could be regarded as a contradiction in terms.

Yet, luxury also is associated with notions of tradition and craftsmanship, art and creativity, respect for materials, quality, and timelessness (Kapferer, 1998; Kapferer and Bastien, 2009; Vigneron and Johnson, 2004). In this sense, luxury could be associated with openness and conservation values, which are highly compatible with CSR-associated selftranscendence values (Schwartz, 1992), such that luxury and CSR are parts of the same principle. These two opposing viewpoints suggest that some factors might accentuate perceptions that luxury and CSR are compatible, whereas others may trigger an opposite perception. This issue has timely and important managerial implications, particularly considering the increased attention that "responsible luxury" has received. Luxury brand managers need a better understanding of the factors they can leverage to achieve successful CSR and marketing strategies if they want to take further steps toward more responsible business practices but avoid the negative consequences of promoting responsible luxury (Torelli et al., 2012).

To fill this research gap, we investigate the roles of two defining characteristics of luxury products_-scarcity (Kemp, 1998) and ephemerality (Berthon et al., 2009)—on the perceived fit between luxury and CSR, that is, on consumers' perceptions of the congruence between a 
luxury product and CSR principles. Furthermore, we investigate how this perceived fit affects consumers' attitudes toward luxury products.

\section{Theoretical Framework and Hypotheses}

\section{The Luxury Concept}

Although many scholars have focused on the nature and definition of luxury (e.g., Fionda and Moore, 2009; Nueno and Quelch, 1998; Vickers and Renand, 2003; Vigneron and Johnson, 1999, 2004), there appears to be little consensus about what it comprises. This confusion may stem partly from its idiosyncratic nature (Kapferer, 1998), in that "what is luxury to one may just be ordinary to another" (Phau and Prendergast, 2000, p. 123). The meaning of luxury notably depends on consumers' own appreciation and experiences, and it may even differ according to their mood (Nia and Zaichhkowsky, 2000). Survey results also indicate that consumers' definition of luxury varies with their socio-demographic profiles, including ages, genders, and ethnic groups (Gardyn, 2002).

Despite this lack of consensus, existing literature consistently suggests that an important, defining characteristic of luxury products is their scarcity or limited availability (Catry, 2003; Dubois and Paternault, 1995; Kapferer, 2004; Kemp, 1998). Research demonstrates that "luxury products are perceived by consumers as rare products; when overdiffused, they gradually lose their luxury character" (Dubois and Paternault, 1995, p. 72). Scarcity may result from two factors (Verhallen and Robben, 1994): popularity or a limited supply. For luxury products, scarcity usually is due to limited supply, which can arise for four reasons: natural scarcity, techno-scarcity, limited edition scarcity, and information-based (or virtual) scarcity (Catry, 2003), as Table 1 details.

\{Insert Table 1 around here $\}$

Luxury products may range from very scarce and almost inaccessible to relatively more accessible (Alleres, 2003). For example, fashion houses such as Dior and Chanel produce 
both haute couture (fashion design) lines and prêt-à-porter (ready-to-wear) clothing. Similarly, the luxury jewelry house Tiffany \& Co. sells both high-end diamond jewelry—such as the Lucida $^{\circledR}$ diamond opera necklace priced at $\$ 2,250,000$ - and more affordable sterling silver and gold jewelry, including the items in the "Return to Tiffany"TM collection, whose prices range from $\$ 75$ to $\$ 5,000$.

\section{The Scarcity Principle}

The scarcity principle posits that scarcity enhances the perceived value of products and that scarce products thus are more desirable than readily available ones (Cialdini, 1985; Lynn, 1991). West's (1975) study of the attractiveness of college cafeteria food was among the first to provide insight into this principle: Respondents who were told that a fire in the cafeteria meant meals would be unavailable for the next couple of weeks offered significantly more positive evaluations of the cafeteria's food than they had the week before, even though there had been no change in the menu, food quality, or food preparation. Psychology literature has examined the principle further (e.g., Lynn, 1989, 1992; Verhallen, 1982; Verhallen and Robben, 1994), as has marketing literature (e.g., Gierl and Huettl, 2010; Inman et al., 1997; Jung and Kellaris, 2004; Suri et al., 2007), noting that companies often use scarcity as a promotional tool (e.g., "limited time only," "in limited supply") to make products appear more desirable.

As we discuss next, the effect of scarcity on consumers' attitudes toward luxury products may be channeled through their perceptions of the fit between the luxury product and CSR (i.e., Luxury-CSR fit). The relative ephemerality of the product also might influence this scarcity effect.

Scarcity, Ephemerality, and the Perceived Luxury-CSR Fit

The adoption of socially responsible behavior results, for example, from the recognition that resources are scarce and fragile and that moderation is key. In keeping with this idea, the 
notion of creative demarketing is relevant; it refers to "that aspect of marketing that deals with discouraging customers in general or a certain class of customers in particular on either a temporary or permanent basis" to diminish demand for a product or service (Kotler and Levy, 1971, p. 75). Offered in the 1970 s as a solution to temporary resource shortages (e.g., Hanna et al., 1975), this concept recently has resurfaced as a potentially more responsible alternative to current marketing practices (Kotler, 2011; Sheth et al., 2011; Sodhi, 2011).

Applying scarcity principles to luxury products (e.g., setting very high prices, producing limited editions, selecting specific distribution channels) could constitute a demarketing approach. Scarcity restricts product availability (Inman et al., 1997) and thereby moderates consumers' consumption. In this sense, the scarcity of luxury products may convey the idea that luxury brands encourage more reasonable, responsible consumption and help protect natural resources. This reasoning is consistent with Kapferer's (2010) assertion that "luxury is resource dependent and obsessed by the sustainability of its resources: high prices limit the demand and is the best way to protect the future of these resources." Thus we expect that a scarce luxury product (as opposed to a more readily available one) evokes a perception of fit with CSR.

However, this expectation might not hold for all types of luxury products. We distinguish products according to their level of ephemerality (Berthon et al., 2009), that is, whether they are enduring or more transitory (i.e., more ephemeral). On the one hand, luxury products traditionally have been associated with endurance; they are items that last (Berthon et al., 2009) or classics that will never go out of fashion (Kapferer, 1998), as aptly summarized by the diamond jeweler De Beers's well-known slogan, "A diamond is forever." On the other hand, luxury products can reflect the latest "hot trend" (Berthon et al., 2009; Stock and Balachander, 2005), with a strong association between notions of luxury and fashion 
(Jackson, 2004). Fashion is ephemeral, transient, and suggestive of short-term cycles and continuous change (Lipovetsky, 1987).

Enduring luxury products. Enduring products, by definition, are long-lasting and durable. An enduring product thus fits with the long-term orientation of a CSR agenda. In addition, many classic products emphasize tradition, quality, art, and craftsmanship (Berthon et al., 2009), and these same aspects often appear in luxury brand communications. For example, De Beers featured reproductions of famous paintings by Picasso, Derain, Dali, and Dufy in print advertisements to convey the idea that diamonds are unique works of art (Epstein, 1982). In other words, enduring products reflect conservation values that appear highly compatible with the self-transcendence values that underlie CSR (Schwartz, 1992).

Ephemeral products. An ephemeral product, by definition, is short-term oriented and carries some connotation of excess or waste (Kahn, 2009), such that it could be perceived as in conflict with CSR considerations. Ephemeral, fashionable products also can be associated more easily with conspicuous consumption and hedonism (Berthon et al., 2009; Evans, 1989; Veblen, 1899), for which the primary concern is consumers' appearance, status, and immediate pleasure. Ephemeral, fashionable products tend to reflect self-enhancement values that conflict with the self-transcendence values underlying CSR (Schwartz, 1992).

We expect that scarcity leads to higher perceived luxury-CSR fit, but only for enduring luxury products that are more compatible with CSR.

$\mathrm{H}_{1}$ : Ephemerality moderates the effect of scarcity on the perceived fit between luxury and corporate social responsibility.

$\mathrm{H}_{2}$ : A higher perceived luxury-CSR fit occurs for scarce products that are enduring.

\section{Effects of CSR Associations on Product Evaluation}

The effect of CSR associations on product evaluations is not straightforward (Luchs et al., 2010; Sen and Bhattacharya, 2001). For example, Luchs et al. (2010) demonstrate that the 
extent to which a positive social or environmental feature enhances product preferences depends on the type of benefit that consumers value most in that product category (e.g., power or safety of cleaning products). Generally though, consumers view socially responsible products positively and appear willing to pay a premium for ethically produced (versus typical) products (Trudel and Cotte, 2009); in a survey of more than 9,000 consumers in eight countries, more than $60 \%$ of the respondents said they prefer to buy products from environmentally responsible companies (Cohn \& Wolfe, 2011). Literature on CSR and sustainability also documents positive marketing effects of CSR associations (e.g., Brown and Dacin, 1997; Choi and Ng, 2011; Mohr and Webb, 2005). For example, Brown and Dacin's (1997) research demonstrates that a favorable CSR record relates positively to overall product evaluations. Thus we expect consumers to exhibit more positive attitudes toward luxury products that are associated with a higher perceived luxury-CSR fit (as in $\mathrm{H}_{1}$ and $\mathrm{H}_{2}$ ):

$\mathrm{H}_{3}$ : Perceived luxury-CSR fit mediates the influence of the joint effect of scarcity and ephemerality on consumers' attitudes toward luxury products.

We present this theoretical framework graphically in Figure 1.

\section{\{Insert Figure 1 around here $\}$}

\section{Methodology}

Design, Stimuli, and Procedure

To test our theoretical framework and hypotheses, we employed a 2 (scarcity: high versus low) $\times 2$ (ephemerality: ephemeral versus enduring) $\times 2$ (replicates) factorial betweensubjects experimental design. We developed eight stimuli/scenarios to represent the combinations of each of the three factors (see Appendix 1).

In a first task, respondents read about a product offered by the hypothetical luxury brand "Eleganza." Using a hypothetical brand ensures the absence of respondents' a priori knowledge about it. Depending on the experimental condition, the product either was 
ephemeral (e.g., item of clothing: dress or jacket) or more enduring (e.g., piece of jewelry: ring or necklace). In addition, the product either was scarce (e.g., haute couture clothes, diamond jewelry) or more readily available (e.g., prêt-à-porter clothes, gold or silver jewelry). Each stimulus featured a product picture and a description that highlighted the product's level of scarcity. Scarcity was created through a combination of natural (rare raw materials), limited edition (number of pieces available), and virtual (price and type of distribution) scarcity cues.

In a second task, respondents completed several items that measured the variables under investigation. At the end of the questionnaire, we added demographic questions, as well as two questions pertaining to the manipulation (ephemerality and scarcity perceptions). All the stimuli and questionnaires were pretested among 49 respondents.

\section{Pretest of Manipulation}

We ran a pretest of the manipulation with 49 respondents who randomly were assigned to one of four scenarios that each included two stimuli (i.e., one item of clothing and one piece of jewelry). Respondents then were asked to rate eight seven-point Likert scales for each stimuli (i.e., three for scarcity and five for ephemerality; 1 = "totally disagree," 7 = "totally agree"). We obtained 97 valid observations. A factor analysis of the eight items revealed two dimensions, as we expected (three scarcity items, $\alpha=.60$; five ephemerality items, $\alpha=.91$ ). Also as expected, the manipulations of scarcity and ephemerality were successful: Scarcity was rated higher in the high versus the low scarcity conditions $(\mathrm{F}(1,95)=77.92, p=.000$; 5.62 versus 3.83), and ephemerality was rated higher in the ephemeral conditions than in the enduring conditions $(\mathrm{F}(1,95)=87.80, p=.000 ; 5.04$ versus 2.68$)$.

\section{Measures}

The measures for the different constructs came from previous literature when applicable but were modified to fit the purpose of our research. The complete list of items appears in Table 2. We measured the perceived luxury-CSR fit with nine items on ten-point Likert 
scales $(1=$ "totally disagree," $10=$ "totally agree"). Our second dependent variable, attitude toward the product, relied on seven items, rated on semantic differential (seven-point) Likert scales. In addition, we included measures for two potential covariates (personal commitment to sustainable development and CSR expectations toward luxury brands), using seven-point Likert scales ( 1 = "totally disagree," 7 = "totally agree"), along with our two manipulation checks items (scarcity and ephemerality).

\{Insert Table 2 around here $\}$

\section{Sample}

Respondents were recruited among students and the general population through posts run on several websites that target women interested in luxury items and the luxury industry. We selected women because they generally are more likely to be interested in buying jewelry for themselves than are men. All respondents were invited to complete our online survey, and those who agreed were assigned randomly to one of the eight experimental conditions. One hundred twenty French women, aged between 18 and 64 years, completed the survey.

\section{Results}

\section{Measurement Checks}

We conducted a factor analysis of the nine items that measured perceived luxury-CSR fit. The screen plot and eigenvalue criteria indicated two factors that explain $49 \%$ and $17 \%$, respectively, of the variance in the data (luxury-CSR fit $1 \alpha=.89$, seven items; luxury-CSR fit $2 \alpha=.75$, two items, correlation between the two fit 2 items is .60). We aggregated the items in the two fit measures by taking their mean. A similar analysis for attitude toward the product showed that the six items loaded on one factor (variance explained $=69 \%, \alpha=.90$ ). Finally, factor analyses of the items pertaining to personal commitment to sustainable development and CSR expectations toward luxury brands resulted in two dimensions 
(variance explained: personal commitment $40 \%, \alpha=.83$, six items; CSR expectations $21 \%, \alpha$ $=.57$, two items, correlation .404).

\section{Manipulation Check}

As expected, respondents rated the stimuli as more ephemeral in the ephemeral conditions than in the enduring conditions $(\mathrm{t}(119)=4.87, p=.000,5.32$ versus 3.82$)$. They also rated the stimuli as more scarce in the high versus low scarcity conditions $(\mathrm{t}(119)=3.75, p=.000 ; 5.06$ versus 3.93).

Influence of Scarcity and Ephemerality on Perceived Luxury-CSR Fit $\left(\mathrm{H}_{1}\right.$ and $\left.\mathrm{H}_{2}\right)$

To test $\mathrm{H}_{1}$, we ran a $2 \times 2 \times 2$ ANOVA for both dimensions of luxury-CSR fit, with ephemerality, scarcity, and replicates as the between-subject factors. As we predicted in $\mathrm{H}_{1}$, ephemerality and scarcity had a multiplicative effect on luxury-CSR fit (fit 1: F(1,113) = 8.377, $p=.005$; fit $2: \mathrm{F}(1,113)=5.185, p=.025)$, as we depict in Figure 2. The main and interaction effects other than ephemerality $\times$ scarcity were not significant $(p>.153)$, with one exception: a main effect of ephemerality on luxury-CSR fit $2(\mathrm{~F}(1,113)=7.940, p=.006)$.

In support of $\mathrm{H}_{2}$, our planned contrast analyses showed that respondents perceived the best fit of scarce, enduring products with CSR (fit $1: \mathrm{t}(117)=24.089, p=.000,4.51$ versus 3.48 [ephemeral, scarce], 3.43 [enduring, less scarce], 4.23 [ephemeral, less scarce]; fit 2: $\mathrm{t}(117)=$ 21.914, $p=.000,5.56$ versus 3.48 [ephemeral, scarce], 5.20 [enduring, less scarce], 4.97 [ephemeral, less scarce]; contrasts: $3,-1,-1,-1)$. Planned contrasts also showed that scarce, enduring products achieved a better fit with CSR than did scarce, ephemeral products (fit 1: $\mathrm{t}(117)=2.325, p=.022$; fit $2: \mathrm{t}(117)=3.456, p=.001)$, whereas there was no significant difference between less scarce, enduring and less scarce, ephemeral products (fit 1: $t(117)=$ $1.939, p>.055$; fit $2: \mathrm{t}(117)=-.412, p>.681$; contrasts: $1,-1,0,0$ and $0,0,-1,1)$.

\{Insert Figure 2 around here $\}$ 
What also emerges from Figure 2 is the total lack of perceived fit with CSR for companies that sell scarce luxury items viewed as ephemeral. The planned contrasts analyses showed that a scarce product appeared socially responsible only if it was enduring; ephemeral, scarce products exhibited the lowest perceived luxury-CSR fit. This result is significant at $\alpha=.05$ for luxury-CSR fit 2 and approaches marginal significance for luxury-CSR fit 1 (fit 1: t(117) $=1.55, p=.125$; fit $2: \mathrm{t}(117)=3.47, p=.001$; contrasts: $-1,3,-1,-1)$.

\section{Mediating Role of Luxury-CSR Fit on Attitude Toward the Product $\left(\mathrm{H}_{3}\right)$}

To test the mediated moderation in which the effect of the independent variable on the mediator depends on the influence of the moderator, we estimated the following equations (Muller et al., 2005).

Luxury-CSR fit $=\beta_{1}+\beta_{2}$ Scarcity $+\beta_{3}$ Ephemerality $+\beta_{4}$ Scarcity $\times$ Ephemerality

Attitude toward the product $=\beta_{5}+\beta_{6}$ Scarcity $+\beta_{7}$ Ephemerality $+\beta_{8}$ Luxury - CSR fit $+\beta_{9}$ Scarcity $\times$ Ephemerality.

We then worked to show that the indirect effect from scarcity $\times$ ephemerality to attitude toward the product, through luxury-CSR fit (i.e., indirect path $b_{4} \times b_{8}$ ), differed significantly from 0, using Preacher and Hayes's (2008) bootstrapping mediation script, as recommended by Zhao et al. (2010).

We detailed the results for Equation 1 in our test of $\mathrm{H}_{1}$. The $\beta$ coefficient for the interaction effect was $-2.045(\mathrm{SE}=.824)$ for luxury-CSR fit 1 and $-1.859(\mathrm{SE}=1.12)$ for luxury-CSR fit 2. When we estimated Equation 2, the interaction term was not significant at $\alpha=.05(\mathrm{~F}(1$, 111) $=3.206, p=.076$ ), but the effects of both dimensions of luxury-CSR fit on attitude toward the product were significant and in the expected positive direction (fit 1 : $F(1,111)=$ 4.736, $p=.032, \beta=.15, \mathrm{SE}=.069 ;$ fit $2: \mathrm{F}(1,111)=10.395, p=.002, \beta=.163, \mathrm{SE}=.051)$. To confirm the robustness of our model, we estimated Equation 2 with the two covariates 
related to commitment to sustainable development and CSR expectations. Neither covariate was significant $(p>.690)$, so the conclusions remained the same.

We then ran Preacher and Hayes's (2008) bootstrapping mediation script. Both indirect effects through luxury-CSR fit 1 and fit 2 were significant, in support of $\mathrm{H}_{3}$ (indirect effect through fit $1=-.271, \mathrm{SE}=.158,95 \%$ confidence interval $\left[\mathrm{CI}_{95}\right]=[-.550 ;-.050]$; indirect effect through fit $\left.2=-.311, \mathrm{SE}=.186, \mathrm{CI}_{95}=[-.622 ;-.030]\right)$. Because the conditions for mediation thus were met (Zhao et al., 2010), we find support for $\mathrm{H}_{3}$ : The perceived fit between luxury and CSR mediates the joint effect of scarcity and ephemerality on product attitude.

\section{Discussion}

Both scarcity and ephemerality dimensions of luxury products influence consumers' perceptions of the fit between the notions of luxury and corporate social responsibility, which in turn affect consumers' attitudes toward these products. When luxury products are scarce, an enduring product is perceived as more socially responsible than an ephemeral one, which leads to more positive attitudes toward the enduring product. Manufacturers or sellers of scarce, ephemeral luxury products thus will find it difficult to position their offerings as responsible, because consumers' perceptions of luxury-CSR fit is lowest for such items. The perceived fit between luxury and CSR underlies the combined effects of scarcity and ephemerality on consumers' attitudes toward luxury products.

\section{Theoretical Contributions}

The democratization of luxury is underway (Thomas, 2007; Truong et al., 2008), leading consumers to "trade up" to luxury products (Silverstein and Fiske, 2003). With this growing market for luxury come new issues for luxury brands, notably with regard to the perceived social and environmental impact of their products. Gaining a better understanding of the factors that affect consumers' evaluations of luxury products and the way they perform those 
evaluations is increasingly important. Yet luxury remains surprisingly seldom investigated. In this context, this study offers several important contributions.

First, most prior work on consumers' attitudes toward luxury has focused on the conceptualizations and connotations of luxury brands (e.g., Nueno and Quelch, 1998; Vigneron and Johnson, 2004) or specific issues such as counterfeiting (Hilton et al., 2004; Wilcox et al., 2009) and brand prominence (Han et al., 2010). To the best of our knowledge, only one recent study on luxury has taken consumers' ethical perceptions into account, by focusing on luxury products' ethical production (Davies et al., 2012). More research is therefore needed to paint a clearer portrait of "responsible luxury." This study responds to this demand by shedding light on consumers' perceptions of the fit between luxury and CSR and demonstrating that scarcity and ephemerality, the defining characteristics of luxury products, influence this perceived fit, which in turn affects consumers' attitudes toward luxury products.

Second, by focusing on luxury, our study extends prior CSR literature, most of which tends to focus on non-luxury goods or other industries, such as tobacco and oil (Yoon et al., 2006). In particular, our findings complement Torelli et al.'s (2012, p. 961) assertion, in a brand concept setting, that "differentiation based on the promotion of a CSR agenda might not be the best strategy for a luxury brand." Our study contributes to the discussion of whether responsible luxury really is a contradiction in terms by showing that the acceptance of responsible luxury appears to depend on the specific characteristics of the advertised luxury product. Specifically, enduring luxury products that enjoy a high level of scarcity, such as diamond jewelry, can convey the idea of an alliance between luxury and CSR. In contrast, if luxury products are more available and/or more ephemeral, they trigger lower perceptions of fit with CSR and prompt less positive consumer attitudes. This latter situation is especially obvious in the case of scarce ephemeral products, such as haute couture clothing, because consumers perceive that these products have minimal fit with CSR principles. 
Third, this study contributes to literature on scarcity. To our knowledge, our work is the first to demonstrate that, when it comes to luxury goods, the value enhancement effect of scarcity moves through consumers' perceptions of fit with CSR, moderated by the level of ephemerality of the product. Accordingly, our study extends literature that has investigated the mechanisms that underlie the scarcity effect, which previously has offered mainly economic rather than ethically oriented explanations, such as assumed expensiveness (Lynn, 1989, 1992) or perceived consumer competition (Aggarwal et al., 2011).

\section{Managerial Implications}

These findings also have important implications for managers who are in charge of luxury brands. In recent years, consumers have exhibited greater sensitivity to social and environmental issues (Cone, 2009); luxury consumers are no exception (Kleanthous, 2011). While research shows that CSR has not significantly affected consumers' luxury purchase decisions so far (Davies et al., 2012), consumers care about responsible luxury, and in coming years, they appear likely to start considering the social and environmental impacts of their luxury purchases.

The luxury sector has suffered various ethical scandals that have placed luxury brands under intensified scrutiny. As Michael Rae, CEO of the Responsible Jewellery Council, points out, "something that is beautifully made, finely crafted, made out of rare materials and well designed, will account for nothing if it is also equated in the public mind with human rights and environmental destruction" (De Beers Group, 2008, p. 26). Responding to these growing concerns, luxury brand managers increasingly initiate CSR projects and disclose more information-which creates another set of risks (Torelli et al., 2012). It therefore is essential for luxury brand managers to gain a clearer understanding of the factors that they can leverage effectively to avoid the potential pitfalls of developing and promoting responsible luxury. This study provides guidelines for managing CSR and marketing strategies; 
specifically, all types of luxury products do not necessarily provoke the same level of perceived fit with CSR and each type should be managed accordingly.

When luxury products are enduring, marketing efforts should focus on making them appear as scarce as possible. Beyond their inherent scarcity, managers can enhance perceived scarcity by maintaining high prices, limiting available quantity, and carefully selecting channels of distribution. The results of our study advise against the ongoing democratization of luxury brands in search of higher profits. Rather, luxury brands should keep their enduring products scarce, not only to preserve those products' luxury character (Dubois and Paternault, 1995) but also to increase their perceived alliance with CSR efforts. In terms of communication strategies, our research suggests luxury brands should emphasize the enduring and scarce character of their products, especially if they aim to provide information about their CSR agenda.

If luxury products are ephemeral though, they are unlikely to trigger a perception of fit with CSR; furthermore, the higher the scarcity level, the lower this perceived fit falls. For such products, luxury brands will likely find it difficult to convey credible CSR messages, unless they take steps to change consumers' perceptions. Although the notion of "responsible fashion" means different things to different people (Friedman, 2010), our findings suggest that a first step to develop more responsible luxury products and increase perceptions of luxury-CSR fit might be to make products more enduring, especially if the brands want to maintain a high level of scarcity. Yves Saint Laurent's New Vintage collection, a line of clothing made entirely of unused fabrics from the brand's past collections (PPR Magazine, 2011), offers a fine example of such an initiative. Our findings suggest luxury brands might want to embrace the slow fashion movement (cf. fast fashion trends prevailing currently), in which products are "made by hand and meant to endure for decades" (Kahn, 2009).

\section{Limitations and Further Research}


Although this study provides several important findings, we acknowledge some limitations that also offer potential avenues for further research. First, a fictitious luxury brand was used in the experiment to limit effects due to differences in consumers' prior knowledge about the brand. Further research should address the effects for familiar brands. In particular, the influence of a luxury brand's existing reputation for CSR might be influential. For example, luxury products sold by a brand previously affected by ethical scandals probably suffers lower perceived fit with CSR, if any; for luxury brands with a more positive CSR track record, even ephemeral products might be perceived as more socially responsible.

Second, a strength of this study is its demonstration that ephemerality moderates the effect of scarcity on the perceived luxury-CSR fit. Yet the exact reason that scarce, ephemeral products appear least responsible remains elusive. Perhaps they elicit perceptions of incongruity due to the contradiction between the notion that scarcity helps protect natural resources and the connotations of excess and waste associated with ephemerality. Previous research indicates that to resolve such an incongruity, consumers elaborate more on information (e.g., Heckler and Childers, 1992), which leads them to discount less diagnostic information in favor of the more diagnostic input to form their judgments (e.g., Aaker and Sengupta, 2000; Chaiken et al., 1989). Furthermore, negative information seems more diagnostic than positive information (e.g., Herr et al., 1991; Skorowski and Carlston, 1989), especially in a morality (versus ability) domain (Martijn et al. 1992). In line with this theory, as well as with recent research demonstrating that perceptions of incongruity related to CSR activities lead to negative company evaluations (Wagner et al., 2009; White and Willness, 2009), we expect that the perceived incongruity triggered by scarce, ephemeral products leads consumers to focus on the (negative) ephemeral character of the product and evaluate it as less responsible than they would if the incongruity were not salient (e.g., for more widely available products). This possible explanation awaits confirmation. 
Third, this experimental study uses typical luxury items as stimuli, yet an emerging trend is the creation of luxury products that are made wholly, or at least in part, from recycled materials. Examples include the luxury jewelry collection Hijau Dua, in which handcrafted pieces of jewelry are made of recycled sterling silver or gold (Grady, 2011), as well as the Vermont Woods Studios' Poly-Wood outdoor furniture line, created from recycled plastic bottles (Vermont Woods Studios, 2011). Common sense might predict that using recycled materials should undermine the products' luxury character, because recycled products have a seemingly enduring reputation for poor quality (Biswas et al., 2000) and because the use of recycled post-consumer waste as raw materials may make the products appear less scarce. Previous research suggests though that consumers view products made of recycled materials to be of similar quality as that of equivalent new products (Hazen et al., 2011; Mobley et al., 1995). Furthermore, the scarcity of the raw materials used in products represents only one of the four scarcity cues that consumers might perceive (Catry, 2003). The presence of recycled materials instead may have a strong positive impact on consumers' perceptions of luxuryCSR fit, regardless of the product's degree of scarcity and ephemerality. In other words, the scarcity and ephemerality of the luxury product in this case may not matter as much as it does in the case of luxury products made from new materials. The type of raw materials (recycled versus new) used to manufacture luxury products therefore may constitute a boundary condition on the effects observed in this study, thus representing an interesting avenue for further research.

Fourth, further research should extend the scope of this study by investigating when and why the use of scarcity tactics for non-luxury products might lead to higher perceptions of fit with CSR principles. More generally, though demarketing offers an alternative to current marketing practices and a means to address CSR issues (Kotler, 2011), more research is needed to uncover how such an approach may generate both social and business returns. 


\section{Acknowledgments}

Jon Reast served as section editor for this article. The authors are grateful for comments on and suggestions for how to improve the article.

\section{References}

Aaker, J.L. \& Sengupta, J. (2000). Additivity versus attenuation: The role of culture in the resolution of information incongruity. Journal of Consumer Psychology, 9(2), 67-82.

Aggarwal, P., Jun, S.Y., \& Huh, J.H. (2011). Scarcity messages: A consumer competition perspective. Journal of Advertising, 40(3), 19-30.

Alleres, D. (2003). Luxe: métiers et management atypiques. Paris: Economica.

Bendell, J. \& Kleanthous, A. (2007). Deeper luxury: Quality and style when the world matters. Available at www.wwf.org.uk/deeperluxury/ (accessed December 20, 2011).

Berthon, P., Pitt, L., Parent, M., \& Berthon, J.-P. (2009). Aesthetics and ephemerality: Observing and preserving the luxury brand. California Management Review, 55(1), 45-66.

Bhattacharya, C.B. \& Sen, S. (2004). Doing better at doing good: When, why, and how consumers respond to corporate social initiatives. California Management Review, 47(1), 9-23.

Biswas, A., Licata, J.W., McKee, D., Pullig, C., \& Daughtridge, C. (2000). The recycling cycle: An empirical examination of consumer waste recycling and recycling shopping behaviors. Journal of Public Policy \& Marketing, 19(1), 93-105.

Bray, J., Johns, N., \& Kilburn, D. (2011). An exploratory study into the factors impeding ethical consumption. Journal of Business Ethics, 98(4), 597-608.

Brown, T.J. \& Dacin, P.A. (1997). The company and the product: Corporate associations and consumer product responses. Journal of Marketing, 61(1), 68-84.

Bruner, G.C. \& Hensel, P.J. (1998). Marketing scales handbook, Vol. 2. Chicago, IL: American Marketing Association. 
Bruner, G.C., Hensel, P.J., \& James, K.E. (2005). Marketing scales handbook, Vol. 4. Chicago, IL: American Marketing Association.

Caixiong, Z. (2011). Letter calls Gucci stores sweatshops. The China Daily News, October 11. Available at www.chinadaily.com.cn/china/2011-10/11/content_13865398.htm (accessed January 7, 2012).

Castro, K. (2009). François-Henri Pinault on sustainable luxury, U.S. News and World Report, March 25, 2009. Available at http://money.usnews.com/money/blogs/luxelife/2009/03/25/franois-henri-pinault-on-sustainable-luxury, (accessed December 20, 2011).

Catry, B. (2003). The great pretenders: The magic of luxury goods. Business Strategy Review, 14(3), 10-17.

Chaiken, S., Liberman, A., \& Eagly, A.H. (1989). Heuristic and systematic information processing within and beyond the persuasion context. In Uleman, J.S. \& Bargh, J.A. (Eds.), Unintended thought. New York: Guilford, pp. 212-252.

Cialdini, R.B. (1985). Influence: Science and practice. Glenview, IL: Scott, Foresman.

Chartrand T.L., Huber, J., Shiv, B., \& Tanner, R.J. (2008). Nonconscious goals and consumer choice. Journal of Consumer Research, 35(2), 189-201.

Choi, S. \& Ng, A. (2011). Environmental and economic dimensions of sustainability and price effects on consumer responses. Journal of Business Ethics, 104(2), 269-282.

Cohn \& Wolfe (2011), The 2011 green brand survey. available at www.cohnwolfe.com/en/ideas-insights/white-papers/green-brands-survey-2011, (accessed December 20, 2011).

Commission of the European Communities (2011), A renewed EU strategy 2011-14 for Corporate Social Responsibility, COM(2011)681. 
Cone (2009), Cone consumer environmental survey fact sheet. Available at www.coneinc.com/stuff/contentmgr/files/0/56cf70324c53123abf75a14084bc0b5e/files/200 9_cone_consumer_environmental_survey_release_and_fact_sheet.pdf, (accessed December 20, 2011).

Davies, I.A., Lee, Z., \& Ahonkhai, I. (2012). Do consumers care about ethical-luxury? Journal of Business Ethics, 106(1), 37-51.

De Beers Group (2008), Luxury: Considered. London: Ledbury Research, available at http://www.debeersgroup.com/en/Media-Centre-Landing-page/Reports/, (accessed July 17, 2012).

Doyle, I. \& Bendell, J. (2011), Uplifting the Earth. The ethical performance of luxury jewellery brands, available at http://www.lifeworth.com/consult/wpcontent/uploads/2011/06/UpliftingTheEarth.pdf, (accessed July 16, 2012).

Dubois, B. \& Paternault, C. (1995). Understanding the world of international luxury brands: The dream formula. Journal of Advertising Research, 3(4), 69-76.

Epstein, E.G. (1982) Have you ever tried to sell a diamond? Atlantic Magazine, February. Available at www.theatlantic.com/magazine/archive/1982/02/have-you-ever-tried-to-sella-diamond/4575/, (accessed December 16, 2011).

Evans, M. (1989). Consumer behaviour towards fashion. European Journal of Marketing, 23(7), 7-16.

Fionda, A.M. \& Moore, C.M. (2009). The anatomy of the luxury fashion brand. Journal of Brand Management, 16(5/6), 347-363.

Friedman, V. (2010). Sustainable fashion: What does green mean? The Financial Times, February 5. Available at www.ft.com/intl/cms/s/2/2b27447e-11e4-11df-b6e300144feab49a.html\#axzz1iWWJu3RW, (accessed January 4, 2012). 
Gardyn, R. (2002). Defining luxury: Oh, the good life. American Demographics. Available at http://findarticles.com/p/articles/mi_m4021/is_2002_Nov_1/ai_93089467/?tag=content;col 1, (accessed December 20, 2011).

Gierl, H. \& Huettl, V. (2010). Are scarce products always more attractive? The interaction of different types of scarcity signals with products' suitability for conspicuous consumption. International Journal of Research in Marketing, 27(3), 225-235.

Grady E. (2011). John Hardy and Angely Lindvall launch luxury recycled jewelry collection. Treehugger, May 7. Available at http://www.treehugger.com/culture/john-hardy-andangela-lindvall-launch-luxury-recycled-jewelry-collection-photos.html (accessed December 19, 2012).

Hagtvedt, H. \& Patrick, V.M. (2009). The broad embrace of luxury: Hedonic potential as a driver of brand extendibility. Journal of Consumer Psychology, 19(4), 608-618.

Han, Y. J., Nunes, J.C., \& Drèze, X. (2010). Signaling status with luxury goods: The role of brand prominence. Journal of Marketing, 74(4), 15-30.

Hanna, N., Kizilbash, A.H., \& Smart, A. (1975). Marketing strategy under conditions of economic scarcity. Journal of Marketing, 39(1), 63-80. Hazen, B.T., Cegielski, C., \& Hanna, J.B. (2011). Diffusion of green supply chain management: Examining perceived quality of green reverse logistics. International Journal of Logistics Management, 22(3), $373-389$.

Hazen, B.T., Cegielski, C., \& Hanna, J.B. (2011). Diffusion of green supply chain management: Examining perceived quality of green reverse logistics. International Journal of Logistics Management, 22(3), 373-389.

Heckler, S.E. \& Childers, T.L. (1992). The role of expectancy and relevancy in memory for verbal and visual information: What is incongruency? Journal of Consumer Research, $18(4), 475-492$. 
Herr, P.M., Kardes, F.R., \& Kim, J. (1991). Effects of word-of-mouth and product-attribute information on persuasion: An accessibility-diagnosticity perspective. Journal of Consumer Research, 17(4), 454-462.

Hilton, B., Choi, C.J., \& Chen, S. (2004). The ethics of counterfeiting in the fashion industry: Quality, credence, and profit issues. Journal of Business Ethics, 55(4), 345-354.

Inman, J.J., Peter, A.C., \& Raghubir, P. (1997). Framing the deal: The role of restrictions in accentuating deal value. Journal of Consumer Research, 24(1), 68-79.

Jackson, T. (2004). A contemporary analysis of global luxury brands. In M. Bruce and T. Hines (Eds.), International Retail Marketing. Oxford: Butterworth-Heinemann, pp. 155169.

Jung, J.M. \& Kellaris, J.J. (2004). Cross-national differences in proneness to scarcity effects: The moderating roles of familiarity, uncertainty avoidance, and need for cognitive closure. Psychology \& Marketing, 21(9), 739-753.

Kahn, J. (2009). Luxury-goods makers embrace sustainability. The New York Times, March 27. Available at www.nytimes.com/2009/03/27/business/worldbusiness/27iht-sustain.html, (accessed August 8, 2011).

Kapferer, J.-N. (1998). Why are we seduced by luxury brands? Journal of Brand Management, 6(1), 44-49.

Kapferer, J.-N. (2004). The new strategic brand management. London: Kogan Page.

Kapferer, J.-N. (2010). All that glitters is not green: The challenge of sustainable luxury. European Business Review, November 15. Available at www.europeanbusinessreview.com/?p=2869, (accessed December 20, 2011).

Kapferer, J.-N. \& Bastien, V. (2009). The specificity of luxury management: Turning marketing upside down. Journal of Brand Management, 16(5/6), 311-322. 
Kemp, S. (1998). Perceiving luxury and necessity. Journal of Economic Psychology, 19(5), 591-606.

Kendal, J. (2010). Responsible luxury: A report on the new opportunities for business to make a difference, The World Jewellery Confederation. Available at www.thecommunicationgroup.co.uk/responsibleluxury/images/responsible_luxury.pdf, (accessed August 8, 2011).

Kleanthous, A. (2011). Simply the best is no longer simple. Raconteur, July 6. Available at http://np.netpublicator.com/netpublication/n10444899, (accessed January 7, 2012).

Kotler, P. (2011). Reinventing marketing to manage the environmental imperative. Journal of Marketing, 75(4), 132-135.

Kotler, P. \& Levy, S.J. (1971). Demarketing, yes, demarketing. Harvard Business Review, 49(6), 74-80.

Lipovetsky, G. (1987), L'Empire de l'éphémère: La mode et son destin dans les sociétés modernes. Paris: Editions Gallimard.

Luchs, M.G., Naylor, R.W., Irwin, J.R., \& Raghunathan, R. (2010). The sustainability liability: Potential negative effects of ethicality on product preferences. Journal of Marketing, 74(5), 18-31.

Lynn, M. (1989). Scarcity effects on value: Mediated by assumed expensiveness? Journal of Economic Psychology, 10(2), 257-274.

Lynn, M. (1991). Scarcity effects on value: A quantitative review of the commodity theory literature. Psychology \& Marketing, 8(1), 43-57.

Lynn, M. (1992). The psychology of unavailability: Explaining scarcity and cost effects on value. Basic and Applied Social Psychology, 13(1), 3-7. 
Maio, G.R., Pakizeh, A., Cheung, W.-Y., \& Rees, K.J. (2009). Changing, priming, and acting on values: Effects via motivational relations in a circular model. Journal of Personality and Social Psychology, 97(4), 699-715.

Mandel, N., Petrova, P.K., \& Cialdini, R.B. (2006). Images of success and the preference for luxury brands. Journal of Consumer Psychology, 16(1), 57-69.

Martijn, C., Spears, R., Van der Pligt, J., \& Jakobs, E. (1992). Negativity and positivity effects in person perception and inference: Ability versus morality. European Journal of Social Psychology, 22(5), 453-463.

Mobley, A.S., Painter, T.S., Untch, E.M., \& Unnava, H.R. (1995). Consumer evaluation of recycled products. Psychology \& Marketing, 12(3), 165-176.

Mohr, L.A., Webb, D.J., \& Harris, K.E. (2001). Do consumers expect companies to be socially responsible? The impact of corporate social responsibility on buying behavior. Journal of Consumer Affairs, 35(1), 45-72.

Mohr, L.A. \& Webb, D.J. (2005). The effects of corporate social responsibility and price on consumer responses. Journal of Consumer Affairs, 39(1), 121-147.

Muller, D., Judd, C.M., \& Yzerbyt, V.Y. (2005). When moderation is mediated and mediation is moderated. Journal of Personality and Social Psychology, 89(6), 852-63.

Nia, A. \& Zaichhkowsky, J.L. (2000). Do counterfeits devalue the ownership of luxury brands? Journal of Product and Brand Management, 9(7), 485-497.

Nueno, J.L. \& Quelch, J.A. (1998). The mass marketing of luxury. Business Horizons, 41(6), $61-68$

Öberseder, M., Schlegelmilch, B.B., \& Gruber, V. (2011). Why don't consumers care about CSR? A qualitative study exploring the role of CSR in consumption decisions. Journal of Business Ethics, 104(4), 449-460. 
Park, CW., Milberg, S.J., \& Lawson, R. (1991). Evaluation of brand extensions: The role of product level similarity and brand concept consistency. Journal of Consumer Research, 18(2), 185-193.

Perry, A. (2011). The return of the blood diamond (and we don't mean the movie). Time, December 5. Available at http://world.time.com/2011/12/05/the-return-of-the-blooddiamond-and-we-dont-mean-the-movie/, (accessed July 10, 2012).

Phau, I. \& Prendergast, G. (2000). Consuming luxury brands: The relevance of the "rarity principle". Journal of Brand Management, 8(2), 122-138.

Pomering, A. \& Dolnicar, S. (2009). Assessing the prerequisite of successful CSR implementation: Are consumers aware of CSR initiatives. Journal of Business Ethics, 85 (Supplement 2), 285-301.

PPR Magazine (2011). Yves Saint Laurent: The new vintage III collection. February. Available at www.ppr.com/en/magazine/issue/48/new-vintage-iii-collection, (accessed January 7, 2012).

Preacher, K.J. \& Hayes, A.F. (2008). Asymptotic and resampling strategies for assessing and comparing indirect effects in multiple mediator models. Behavior Research Methods, 40(3), 879-91.

Schwartz, S.H. (1992). Universals in the content and structure of values: Theoretical advances and empirical tests in 20 countries. In Zanna, M.P. (Ed.), Advances in experimental social psychology, Vol. 25. San Diego, CA: Academic Press, 1-65.

Schwartz, S.H. \& Rubel, T. (2005). Sex differences in value priorities: Cross-cultural and multimethod studies. Journal of Personality and Social Psychology, 89(6), 1010-1028.

Sen, S. \& Bhattacharya, C.B. (2001). Does doing good always lead to doing better? Consumer reactions to corporate social responsibility. Journal of Marketing Research, 38(2), 225243. 
Sheth, J.N., Sethia, N.K., \& Srinivas, S. (2011). Mindful consumption: A customer-centric approach to sustainability. Journal of the Academy of Marketing Science, 39(1), 21-39.

Silverstein, M.J. \& Fiske, N. (2003). Luxury for the masses. Harvard Business Review, 81(4), $48-57$.

Skowronski, J.J. \& Carlston, D.E. (1989). Negativity and extremity in impression formation: A review of explanations. Psychological Bulletin, 105(1), 131-142.

Sodhi, K. (2011). Has marketing come full circle? Demarketing for sustainability. Business Strategy Series, 12(4), 177-185.

Stock, A. \& Balachander, S. (2005). The making of a hot product: A signaling explanation of marketers' scarcity strategy. Management Science, 51(8), 1181-1192.

Suri, R., Kohli, C., \& Monroe, K.B. (2007). The effects of perceived scarcity on consumers' processing of price information. Journal of the Academy of Marketing Science, 35(1), 89100.

Thomas, D. (2007), Deluxe: How luxury lost its luster. London: The Penguin Press.

Tonello, M. (2008), Bringing home the Birkin: My life in hot pursuit of the world's most coveted handbag. New York: Harper Collins.

Torelli, C.J., Monga, A.S.B., \& Kaikati, A.M. (2012). Doing poorly by doing good: Corporate social responsibility and brand concepts. Journal of Consumer Research, 38(5), 948-963.

Trudel, R. \& Cotte, J. (2009). Does it pay to be good? MIT Sloan Management Review, 50(2), $61-68$

Truong, Y., McColl, R., \& Kitchen, P.J. (2008). New luxury brand positioning and the emergence of masstige brands. Journal of Brand Management, 16(5/6), 375-382.

Van Marrewijk, M. (2003). Concept and definitions of CSR and corporate sustainability: Between agency and communion. Journal of Business Ethics, 44(2/3), 95-105.

Veblen, T.B. (1899), The theory of the leisure class. Boston, MA: Houghton Mifflin. 
Verhallen, T.M. (1982). Scarcity and consumer choice behavior. Journal of Economic Psychology, 2(2), 299-321.

Verhallen, T.M. \& Robben, H.S.J. (1994). Scarcity and preference: An experiment on unavailability and product evaluation. Journal of Economic Psychology, 15(2), 315-331.

Vermont Woods Studios (2011). Press release: Vermont Furniture Company introduces luxury Poly-Wood outdoor furniture made from recycled plastic bottles. PR.com, March 25. Available at http://www.pr.com/press-release/308267 (accessed December 19, 2012).

Vickers, J.S. \& Renand, F. (2003). The marketing of luxury goods: An exploratory studyThree conceptual dimensions. The Marketing Review, 3(4), 459-478.

Vigneron, F. \& Johnson, L.W. (1999). A review and a conceptual framework of prestigeseeking consumer behavior. Academy of Marketing Science Review, 99(1), 1-15.

Vigneron, F. \& Johnson, L.W. (2004). Measuring perceptions of brand luxury. Journal of Brand Management, 11(6), 484-506.

Wagner, T., Lutz, R.J., \& Weitz, B.A. (2009). Corporate hypocrisy: Overcoming the threat of inconsistent corporate social responsibility perceptions. Journal of Marketing, 73(6), 7791.

West, S.G. (1975). Increasing the attractiveness of college cafeteria food: A reactance theory perspective. Journal of Applied Psychology, 60(5), 656-658.

White, K. \& Willness, C. (2009). Consumer reactions to the decreased usage message: The role of elaborative processing. Journal of Consumer Psychology, 19(1), 73-87.

Wilcox, K., Kim, H.M., \& Sen, S. (2009). Why do consumers buy counterfeit luxury brands? Journal of Marketing Research, 46(2), 247-259.

Wilkinson, T. (2008). Slaving in the lap of luxury. Los Angeles Times, February 20. Available at http://articles.latimes.com/2008/feb/20/world/fg-madeinitaly20, (accessed July 10, 2012). 
Yoon, Y., Gürhan-Canli, Z., \& Schwarz, N. (2006). The effect of corporate social responsibility (CSR) activities on companies with bad reputations. Journal of Consumer Psychology, 16(4), 377-390.

Zhao, X., Lynch, J.G., \& Chen, Q. (2010). Reconsidering Baron and Kenny: Myths and truths about mediation analysis. Journal of Consumer Research, 37(2), 197-205. 


\section{Appendix 1: Stimuli (translated from French)}

Scarce, Ephemeral Products

\begin{tabular}{|l|l|}
\hline Replicate 1: Haute couture dress & Replicate 2: Haute couture jacket \\
\hline $\begin{array}{l}\text { The brand Eleganza presents a haute couture } \\
\text { piece of clothing from its latest collection that } \\
\text { follows this season's fashion trends. This } \\
\text { sleeveless dress has ornaments cut on the } \\
\text { waist and a side collar with embroidered }\end{array}$ & $\begin{array}{l}\text { The brand Eleganza a haute couture } \\
\text { piece of clothing from its latest collection } \\
\text { that follows this season's fashion trends. } \\
\text { This jacket has decorative stitching and }\end{array}$ \\
$\begin{array}{l}\text { feathers (black georgette and black ostrich feathers, } \\
\text { lining in crepe-de-Chine, dress 98\% silk, and 2\% } \\
\text { spandex). }\end{array}$ & $\begin{array}{l}\text { Its price is } € 5,500, \text { and only 10 of these jackets } \\
\text { exist worldwide; they are available only at the } \\
\text { brand's flagship store located on Avenue } \\
\text { Its price is } € 7,300, \text { and only } 10 \text { of these dresses exist } \\
\text { Morldwide; they are available only at the brand's }\end{array}$ \\
$\begin{array}{l}\text { Montaigne. } \\
\text { flagship store located on Avenue Montaigne. }\end{array}$
\end{tabular}

Less Scarce, Ephemeral Products

\begin{tabular}{|l|l|}
\hline Replicate 1: Prêt-à-porter dress & Replicate 2: Prêt-à-porter jacket \\
\hline $\begin{array}{l}\text { The brand Eleganza offers in this year's } \\
\text { collection this high-end piece of clothing (prêt-à- } \\
\text { porter) that follows this season's fashion trend. } \\
\text { This long-sleeved dress has a drop-shaped } \\
\text { neckline and decoration in gold metal (94\% }\end{array}$ & $\begin{array}{l}\text { The brand Eleganza offers in this year's } \\
\text { collection this high-end piece of clothing } \\
\text { (prêt- } \text { à-porter) that follows this season's } \\
\text { fashion trend. This beige felt reefer jacket }\end{array}$ \\
$\begin{array}{l}\text { viscose, } 4 \% \text { polyamide, and } 2 \% \text { polyurethane). } \\
\text { Its price is } € 1,990, \text { and this item is available at all of the } \\
\text { brand's prêt-à-porter stores. }\end{array}$ & $\begin{array}{l}\text { Its price is } € 1,690, \text { and this item is available at all } \\
\text { of the brand's prêt- } \grave{a} \text {-porter stores. }\end{array}$ \\
\hline
\end{tabular}

Scarce, Enduring Products

\begin{tabular}{|l|l|}
\hline Replicate 1: Diamond ring & Replicate 2: Diamond necklace \\
\hline $\begin{array}{l}\text { The brand Eleganza presents, from its latest } \\
\text { jewelry collection, this 18K yellow gold ring } \\
\text { with brown diamonds. This ring can be } \\
\text { passed down from generation to generation. }\end{array}$ & $\begin{array}{l}\text { The brand Eleganza presents, from its } \\
\text { latest jewelry collection, this 18K white } \\
\text { gold and beryl necklace, encrusted with } 63 \\
\text { diamonds. This necklace can be passed }\end{array}$ \\
$\begin{array}{l}\text { Its price is } € 7,300 \text {, and only } 10 \text { of these rings exist; they } \\
\text { are available only at the brand's flagship store located } \\
\text { on Avenue Montaigne. }\end{array}$ & $\begin{array}{l}\text { Its price is } € 5,500, \text { and only } 10 \text { of these necklaces } \\
\text { exist; they are available only at the brand's flagship } \\
\text { store located on Avenue Montaigne. }\end{array}$ \\
\hline
\end{tabular}

Less Scarce, Enduring Products

\begin{tabular}{|l|l|}
\hline Replicate 1: gold ring & Replicate 2: gold necklace \\
$\begin{array}{l}\text { The brand Eleganza offers in its permanent } \\
\text { jewelry collection this ring in 18K yellow } \\
\text { gold. }\end{array}$ & $\begin{array}{l}\text { The brand Eleganza offers in its } \\
\text { permanent jewelry collection this } \\
\text { necklace in 18K white gold. }\end{array}$ \\
$\begin{array}{l}\text { Its price is } € 1,990, \text { and the ring is available at all of the } \\
\text { brand's stores. }\end{array}$ & $\begin{array}{l}\text { Its price is } € 1,690 \text {, and the necklace is available at } \\
\text { all of the brand's stores. }\end{array}$ \\
\hline
\end{tabular}


Table 1: Types and Examples of Scarcity

\begin{tabular}{|c|c|c|}
\hline Type of Scarcity & Description & Example(s) \\
\hline Natural scarcity & $\begin{array}{l}\text { Shortages of raw ingredients } \\
\text { or components. }\end{array}$ & $\begin{array}{l}\text { Diamonds, black pearls, or } \\
\text { grand cru wines; limited } \\
\text { availability of the human } \\
\text { expertise needed to } \\
\text { "handcraft" the products. }\end{array}$ \\
\hline Techno-scarcity & $\begin{array}{l}\text { Continuous investment (or } \\
\text { lack thereof) in innovative } \\
\text { product features, which allow } \\
\text { products to be ahead of their } \\
\text { time and differentiated as } \\
\text { "evidence of progress." }\end{array}$ & $\begin{array}{l}\text { Tag Heuer's Mikrotimer } \\
\text { Flying } 1000 \text { concept watch, } \\
\text { presented in January } 2011, \\
\text { was the first and only } \\
\text { mechanical chronograph to } \\
\text { measure and display the } \\
\text { 1/1,000th of a second. }\end{array}$ \\
\hline Limited edition & $\begin{array}{l}\text { A limited number of } \\
\text { products, perhaps even } \\
\text { individually tailored luxury } \\
\text { products. }\end{array}$ & $\begin{array}{l}\text { The limited edition of Louis } \\
\text { Vuitton's "Eye Love You" } \\
\text { handbag, designed by Marc } \\
\text { Jacobs and Takashi } \\
\text { Murakami. }\end{array}$ \\
\hline $\begin{array}{l}\text { Information-based (or } \\
\text { virtual) scarcity }\end{array}$ & $\begin{array}{l}\text { Information carefully } \\
\text { communicated to consumers, } \\
\text { such as high selling prices, } \\
\text { selective distribution, or } \\
\text { implied by trendy and chic } \\
\text { advertising and public } \\
\text { relations events. Also } \\
\text { referred to as "illusory" } \\
\text { scarcity. }\end{array}$ & $\begin{array}{l}\text { Two-year waiting list to buy } \\
\text { the Hermès Birkin handbag } \\
\text { (Tonello, 2008). Virtual } \\
\text { scarcity often works with } \\
\text { the three other types of } \\
\text { scarcity (e.g., diamond } \\
\text { jewelry sold at a high price } \\
\text { through selective } \\
\text { distribution). }\end{array}$ \\
\hline
\end{tabular}


Table 2: Measures

\begin{tabular}{|c|c|c|}
\hline \multicolumn{2}{|c|}{ Concept Measured } & Items \\
\hline \multirow{9}{*}{$\begin{array}{l}\text { Perceived fit } \\
\text { between } \\
\text { luxury and } \\
\operatorname{CSR}^{(1)}\end{array}$} & Luxury & This is a product created in a responsible way. \\
\hline & $-\mathrm{CSR}$ & This is a product created in accordance with ethical principles. \\
\hline & & This luxury product seems to be made of ecological materials. \\
\hline & & This luxury product was created from a sustainability perspective. \\
\hline & & This luxury product was created in accordance with moral principles. \\
\hline & & This luxury product is eco-aware. \\
\hline & & $\begin{array}{l}\text { This luxury product allows for a comfortable life while preserving the } \\
\text { planet. }\end{array}$ \\
\hline & $\begin{array}{l}\text { Luxury } \\
- \text { CSR }\end{array}$ & $\begin{array}{l}\text { This luxury product does not waste resources in order to fulfill } \\
\text { secondary needs. }\end{array}$ \\
\hline & fit 2 & This luxury product is not synonymous with excess and abundance. \\
\hline \multirow{6}{*}{\multicolumn{2}{|c|}{$\begin{array}{l}\text { Attitude toward the } \\
\text { product }^{(2)}\end{array}$}} & I like (dislike) this product. \\
\hline & & Owning this product is perceived (un)favorably by others. \\
\hline & & I think this is a good (bad) product. \\
\hline & & \\
\hline & & I have positive (negative) feelings toward that product. \\
\hline & & I feel (un)favorable toward this product. \\
\hline \multirow{5}{*}{\multicolumn{2}{|c|}{ Ephemerality ${ }^{(1)}$}} & $\begin{array}{l}\text { This product can be worn for years after years and will never go out } \\
\text { of fashion. }\end{array}$ \\
\hline & & This product is worn and passed down from generation to generation. \\
\hline & & This product lasts forever. \\
\hline & & This product is part of a passing trend. \\
\hline & & This product is ephemeral. \\
\hline \multirow{3}{*}{\multicolumn{2}{|c|}{ Scarcity $^{(1)}$}} & This product is unique, original. \\
\hline & & This product is made of rare and precious materials. ${ }^{(3)}$ \\
\hline & & This product can easily be found. \\
\hline \multirow{2}{*}{\multicolumn{2}{|c|}{$\begin{array}{l}\text { Personal commitment } \\
\text { to sustainable } \\
\text { development }^{(1)}\end{array}$}} & $\begin{array}{l}\text { When shopping, do you take into account sustainable development } \\
\text { considerations? }\end{array}$ \\
\hline & & $\begin{array}{l}\text { Would you be willing to buy more luxury products if it was proven to } \\
\text { you that they respect sustainable development values? }\end{array}$ \\
\hline \multirow{7}{*}{\multicolumn{2}{|c|}{$\begin{array}{l}\text { CSR expectations of } \\
\text { luxury brands }{ }^{(1)(4)}\end{array}$}} & Luxury brands have to protect endangered species. \\
\hline & & $\begin{array}{l}\text { Luxury brands must take part in the efforts made to reduce water } \\
\text { consumption. }\end{array}$ \\
\hline & & It is important for luxury brands to use recycled packaging. \\
\hline & & It is important for luxury brands not to exploit their employees. \\
\hline & & $\begin{array}{l}\text { Luxury brand have to fight against climate change (production and } \\
\text { transportation of products). }\end{array}$ \\
\hline & & $\begin{array}{l}\text { Luxury brands must take part in the efforts made to reduce energy } \\
\text { consumption. }\end{array}$ \\
\hline & & $\begin{array}{l}\text { It is important for luxury brands to educate their employees about } \\
\text { their impact on the environment. }\end{array}$ \\
\hline
\end{tabular}


${ }^{(1)}$ Items are translated from French.

(2) Adapted from scales by Chattopadhyay and Basu, Ratneshwar and Chaiken, and Fisher and Price (listed in Bruner and Hensel, 1998) or by Hui et al. (listed in Bruner et al., 2005).

${ }^{(3)}$ Items used for the manipulation check in the final experiment.

(4) Based on items from Bhattacharya and Sen (2004). 
Figure 1: Research Model

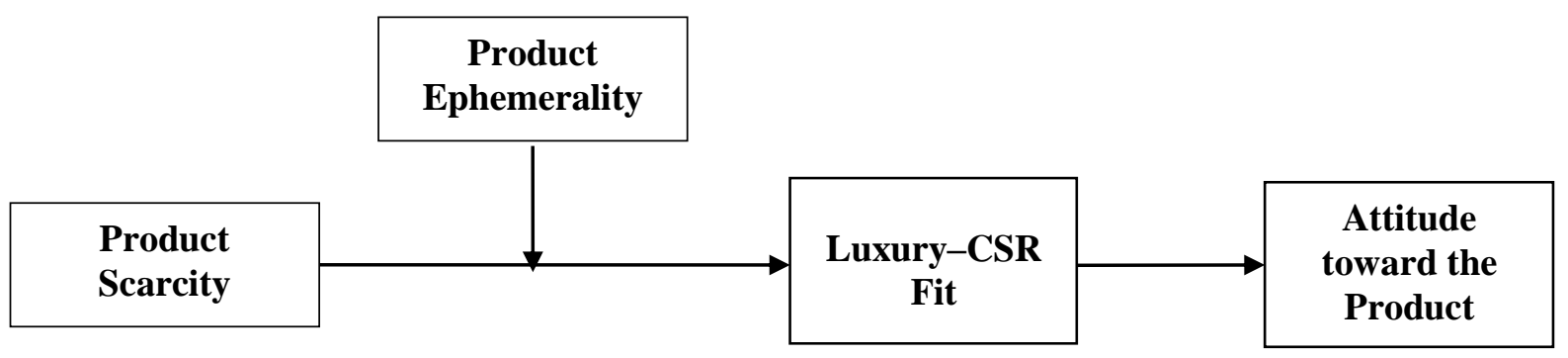


Figure 2: Scarcity $\times$ Ephemerality Effects on Luxury-CSR Fit

(a) Scarcity $\times$ Ephemerality Effects on Luxury-CSR Fit 1

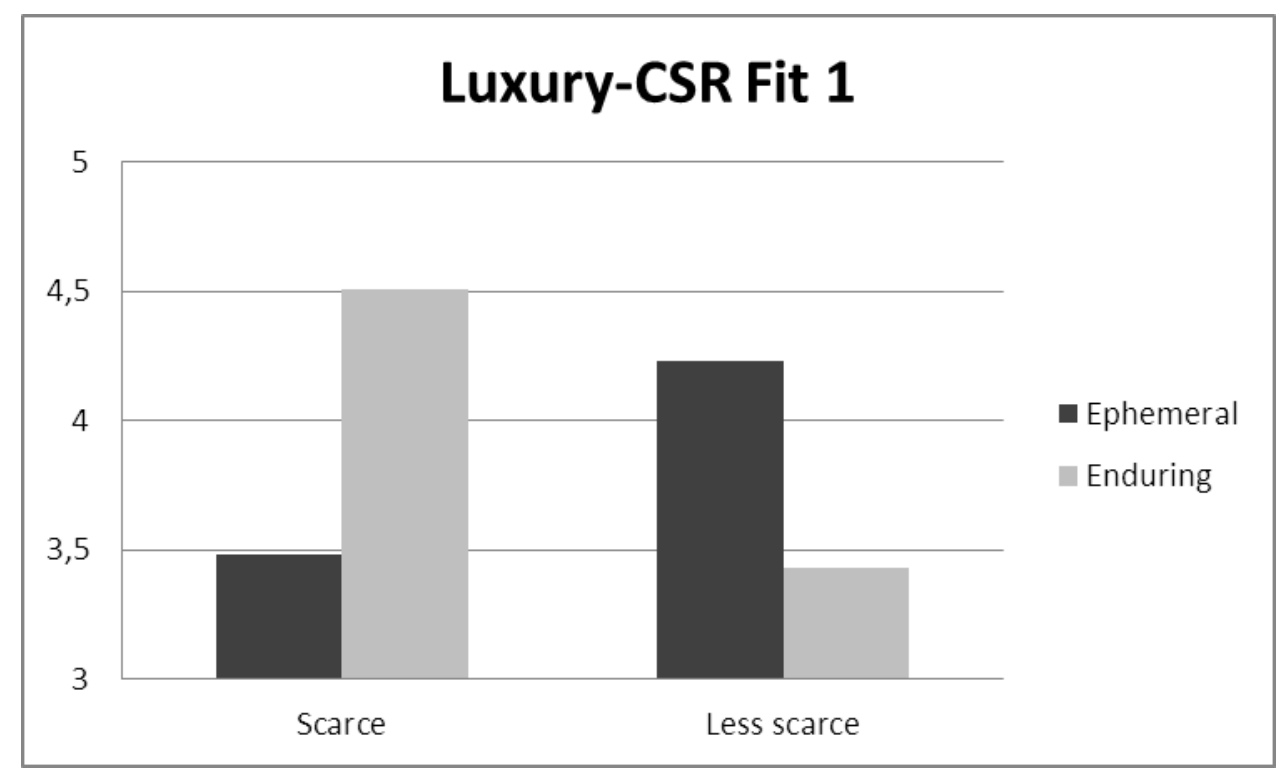

(b) Scarcity $\times$ Ephemerality Effects on Luxury-CSR Fit 2

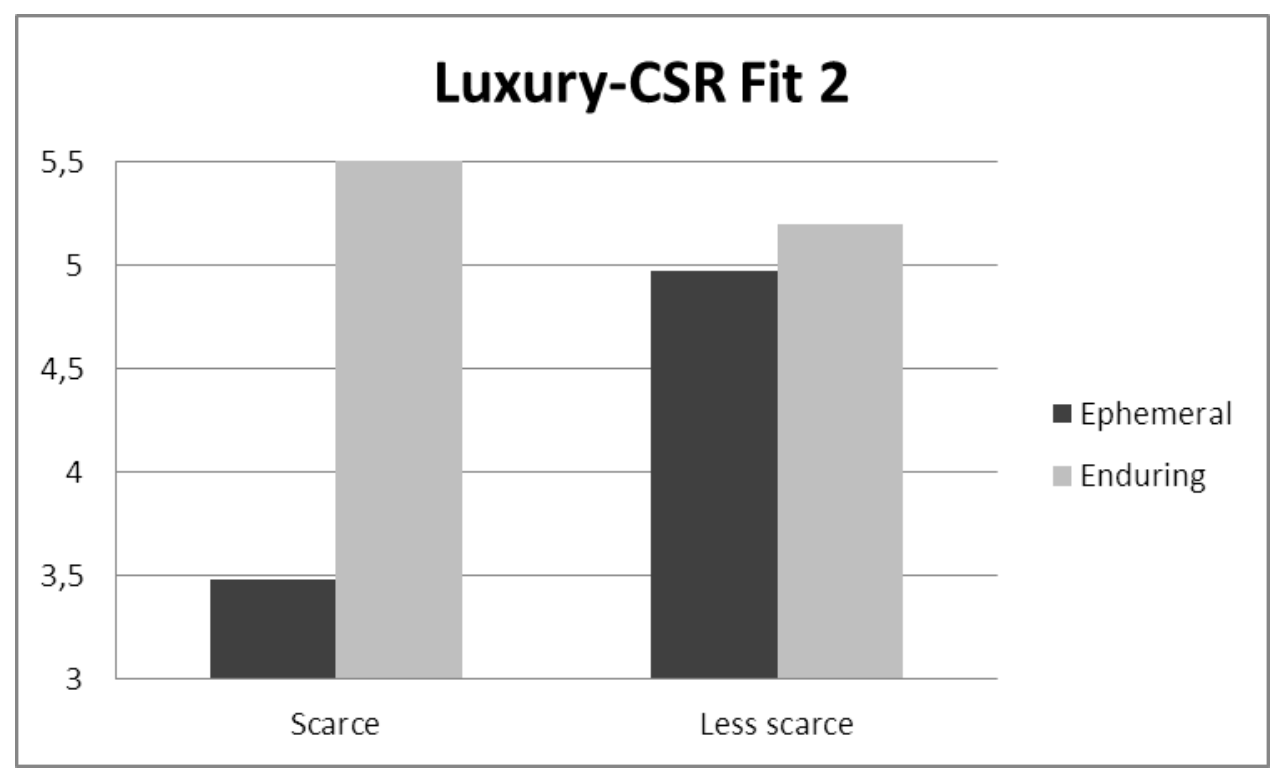

